\title{
Effect of oral mucosal transplantation on the expression of EGF and VEGF-C during skin wound repair
}

\author{
SHUMEI QI ${ }^{1 *}$, CHANGXI YANG ${ }^{2 *}$, MINGZHEN ZHU $^{3}$ and HUI CHEN ${ }^{4}$ \\ ${ }^{1}$ Department of Stomatology, Jinan Maternity and Child Care Hospital, Jinan, Shandong 250001; \\ ${ }^{2}$ Department of Stomatology, Zibo Mining Group Central Hospital, Zibo, Shandong 255120; \\ Departments of ${ }^{3}$ Stomatology and ${ }^{4}$ Endodontics, Jinan Stomatological Hospital, \\ Jinan, Shandong 250001, P.R. China
}

Received December 4, 2018; Accepted April 11, 2019

DOI: $10.3892 / \mathrm{etm} .2019 .7546$

\begin{abstract}
This study evaluated the effects of oral mucosal transplantation on epidermal growth factor (EGF) and vascular endothelial growth factor $\mathrm{C}$ (VEGF-C) in skin wound repair. Sixty-four rats were randomly separated into group A, B, C and $\mathrm{D}$ (16 rats in each group). The right abdomen skin was excised 1,3,5 and 7 days after injury, respectively. Oral mucosa of the rat tongue was transplanted to the right abdomen skin. Fourteen days after the healing of the oral mucosa graft, the rat skin full-thickness model was prepared at the transplant site (the study group) and the contralateral site (the control group). Rats in each group were anesthetized and sacrificed at 1, 3, 5 and 7 days after injury. Expression of EGF and VEGF-C in skin tissue was detected by RT-qPCR and ELISA. At 3 days, expression levels of EGF and VEGF-C mRNA and protein in skin tissue were significantly higher than those at 1 day $(\mathrm{P}<0.05)$. At 5 days, expression levels of EGF and VEGF-C mRNA and protein in skin tissue were significantly higher than those at 3 days $(\mathrm{P}<0.05)$. At 7 days, expression levels of EGF mRNA and protein in skin tissue were significantly lower than those at 5 days $(\mathrm{P}<0.05)$, while VEGF-C levels were significantly increased $(\mathrm{P}<0.05)$. Expression levels of EGF and VEGF-C mRNA and protein in the skin tissue of the study group were significantly lower than those in the control group at all days $(\mathrm{P}<0.05)$. EGF and VEGF-C may be involved
\end{abstract}

Correspondence to: Dr Mingzhen Zhu, Department of Stomatology, Jinan Stomatological Hospital, 101 Jingliu Road, Jinan, Shandong 250001, P.R. China

E-mail: mingzhen_zhu01@163.com

Dr Hui Chen, Department of Endodontics, Jinan Stomatological Hospital, 101 Jingliu Road, Jinan, Shandong 250001, P.R. China E-mail: chenhui328404@126.com

${ }^{*}$ Contributed equally

Key words: oral mucosa transplantation, skin wound repair, epidermal growth factor, vascular endothelial growth factor $\mathrm{C}$, scar in scar formation, and play an important role in the process of skin wound repair.

\section{Introduction}

Skin wound repair often results in the formation of scar tissue (1). Despite efforts, scars still cannot be avoided in clinical practice. Compared with skin, oral mucosa has the characteristics of quick healing and less scar tissue formation (2). Therefore, it is of great significance to study the factors of scar formation and the biological indicators in the process of skin wound repair. Wound repair is a complex process of interaction between cells, growth factors and extracellular matrices (3). Epidermal growth factor (EGF) is a heat-resistant single-chain polypeptide that can bind to cell membrane receptors and exert various biological effects (4). EGF, a potent mitogenic factor, promotes epithelial cell proliferation and division, improves collagen construction and regulates protein synthesis, thereby accelerating wound healing. EGF has chemotactic effects on vascular endothelial cells, fibroblasts, inflammatory cells and epidermal cells (5). Vascular endothelial growth factor C (VEGF-C) is a member separated from the vascular endothelial growth factor (VEGF)/platelet-derived factor (PDGF) family and is the fourth member of the VEGF subfamily. VEGF-C gene includes seven exons and is the largest VEGF gene currently described (6). Previous research has shown that high expression of VEGF-C plays an important role in the angiogenesis of limb ischemia in adult animals (7).

The moisture of oral mucosa is different from that of skin. Some scholars believe that the oral mucosa can be repaired with little or no scar because of the moisture and salivary protease $(8,9)$. In order to further clarify the factors in the process of scar formation and skin wound repair, the rat oral mucosa was transplanted to the right abdomen in this study. By comparing the differences in the expression of EGF and VEGF-C during skin healing, the role of the two factors in scar formation and skin wound repair was revealed.

\section{Materials and methods}

Experimental animals. Sixty-four inbred strain SPF SD rats (150-190 g, 4-8 weeks) were purchased from Kaixue 
Table I. Primers of EGF mRNA, VEGF-C mRNA and $\beta$-actin.

\begin{tabular}{lcc}
\hline Gene & \multicolumn{1}{c}{ Forward primers } & \multicolumn{1}{c}{ Reverse primers } \\
\hline EGF & 5'-TGCCAACTGGGGGTGCACAG-3' & 5'-CTGCCCGTGGCCAGCGTGGC-3' \\
VEGF-C & 5'-TTCCATTATTAGACGTTCCCTG-3' & 5'-GTGTTTTCATCAAATTCTCGGT-3' \\
$\beta$-actin & 5'-AAATCGTGCGTGACATTAA-3' & 5'-CTCGTCATACTCCTGCTTG-3'
\end{tabular}

EGF, epidermal growth factor; VEGF-C, vascular endothelial growth factor C.

Biological Science and Technology (Shanghai) Co., Ltd. [SCXK (Shanghai) 2009-0037; Shanghai, China]. Rats were kept in a clean environment with good ventilation. The indoor humidity was $48-59 \%$, and the temperature was $21-26^{\circ} \mathrm{C}$. Rats were fed with SPF experimental rat food provided by Jiangsu Synergy Pharmaceutical Bioengineering Co., Ltd. (Jiangsu, China). Rats had free access to food and water.

The investigation was approved by the Ethics Committee of Jinan Maternity and Child Care Hospital (Jinan, China) and the experimental procedures were in compliance with the Guiding Principles for the Protection and Use of Experimental Animals (10). Patients who participated in this research had complete clinical data. Signed informed consents were obtained from the patients or the guardians.

Animal model preparation. The 64 inbred strain SPF SD rats were randomly separated into group A, B, C and D (16 rats in each group) according to the principle of similar weight. Ten percent chloral hydrate were used for intraperitoneal injection anesthesia at a dose of $350 \mathrm{mg} / \mathrm{kg}$. The abdomen of the rat faced up, and the limbs were immobilized. The right abdomen of the rat was first transplanted with oral mucosa. The full-thickness skin with a diameter of $1 \mathrm{~cm}$ of the right abdomen of the rat was cut. The skin was transplanted to the skin of the right abdomen and then sutured and bandaged. After that, rats were placed in a squirrel cage with free access to water and food. When the wound of the oral mucosa was healed for 14 days, intraperitoneal injection anesthesia was performed with the same dose of chloral hydrate, and then a full-thickness skin incision was made on the right abdomen of the rat with a round blade. The incision was deep to fascia layfer and was $1 \mathrm{~cm}$ in diameter. The same cut was made in the left abdomen of the rats and the wound diameter was $1 \mathrm{~cm}$. Rats were allowed to reach food and water freely for a week. Rats in group A, B, C and D were anesthetized with chloral hydrate $(350 \mathrm{mg} / \mathrm{kg})$ and sacrificed by cervical dislocation 1,3,5 and 7 days after injury. Skin tissue with a diameter of about $1.5 \mathrm{~cm}$ around the center of the wound was collected. Skin tissue of the right abdomen was the study group, and the left abdomen skin tissue was the control group, being cryopreserved after collection.

Indicator detection. Expression of EGF mRNA and VEGF-C mRNA in skin tissue were detected by RT-qPCR. Appropriate amount of tissue was washed twice with PBS, and the total RNA extraction of skin tissue was carried out in strict accordance with the instructions of TRIzol extraction kit (Shanghai Yusheng Biotechnology Co., Ltd., Shanghai, China). Absorbance of the RNA was measured using an ultraviolet-visible spectrophotometer (MettlerToledo International Trading Co., Ltd., Shanghai, China), and the concentration of RNA sample was calculated. One micrograms of RNA was reverse-transcribed into cDNA, and cDNA was prepared according to the instructions of M-MLV reverse transcription kit (Hanheng Biotechnology Co., Ltd., Shanghai, China). Reverse transcription reaction conditions: $42^{\circ} \mathrm{C}$ for $60 \mathrm{~min}$ and $85^{\circ} \mathrm{C}$ for $5 \mathrm{~min}$, termination reaction at $4^{\circ} \mathrm{C}$. Synthesized cDNA was stored at $-20^{\circ} \mathrm{C}$. Ten microliters of reaction system was prepared according to the instruction of Takara Real-Time PCR (Beijing Borma Biotechnology Co., Ltd., Beijing, China). Ten microliters of reaction system included $50 \mathrm{ng}$ of total RNA, PCR Premix, double distilled water, ROX Dye and $200 \mathrm{nM}$ primers. $\beta$-actin was used as an internal reference. Primer sequences are shown in Table I. Reaction procedure included 40 cycles of $95^{\circ} \mathrm{C}$ for $30 \mathrm{sec}$ and $60^{\circ} \mathrm{C}$ for $33 \mathrm{sec}$. The experiment was repeated 3 times. Amplification data were analyzed by vendor software and the expression of EGF mRNA and VEGF-C mRNA was calculated by $2^{-\Delta \mathrm{Cq}}$ method (11).

Expressions of EGF protein and VEGF-C protein in skin tissue were detected by ELISA. Appropriate amount of skin tissue was taken and washed in pre-cooled PBS (0.02 mol/1, $\mathrm{pH} 7.0-7.2)$ to remove blood, then crushed to prepare homogenate. The homogenate was centrifuged at $5,000 \mathrm{x} \mathrm{g}$ for $5 \mathrm{~min}$ at $4^{\circ} \mathrm{C}$, and the supernatant was saved. EGF and VEGF-C ELISA assay kit (cat. nos. DEG00 and DVEC00; R\&D Systems, Minneapolis, MN, USA) was used for the detection in accordance with the instructions. The sample and the kit was taken to room temperature $45 \mathrm{~min}$ in advance from the refrigerator, and the sample well, standard well and blank well were set. No reagents were added to the blank well. The sample well and the standard well were added with $50 \mu \mathrm{l}$ of the sample to be tested and standard diluted in different multiples, respectively, with $50 \mu 1$ of biotin-labeled antibody. The membrane was covered, and incubated at $37^{\circ} \mathrm{C}$ for $1 \mathrm{~h}$. Liquid in each well was discarded, dried, and washed 3 times. Affinity streptavidin $(80 \mu \mathrm{l})$ was added to each well, mixed and incubated at $37^{\circ} \mathrm{C}$ for $30 \mathrm{~min}$. Liquid was discarded in each well, dried, and washed 3 times. Substrate A and B at $50 \mu \mathrm{l}$ each, were added to the wells, mixed and incubated at $37^{\circ} \mathrm{C}$ for $10 \mathrm{~min}$. A color change was produced in the dark at room temperature. Fifty microliters of the stop solution was added to each well, and the OD value of each well was measured at a wavelength of $450 \mathrm{~nm}$ using a 680 automatic microplate reader (Bio-Rad, Hercules, CA, USA) to calculate the expression levels of EGF and VEGF-C proteins. 
Table II. General condition of rats $[\mathrm{n}(\%)]($ mean $\pm \mathrm{SD})$.

\begin{tabular}{|c|c|c|c|c|c|c|}
\hline Items & $A(n=16)$ & $B(n=16)$ & $C(n=16)$ & $D(n=16)$ & $\mathrm{F} / \chi^{2}$ & P-value \\
\hline Sex & & & & & 4.726 & 0.193 \\
\hline Male & $11(68.75)$ & $9(56.25)$ & $14(87.50)$ & $13(81.25)$ & & \\
\hline Female & $5(31.25)$ & $7(43.75)$ & $2(12.50)$ & $3(18.75)$ & & \\
\hline Age (weeks) & $8.41 \pm 0.27$ & $8.32 \pm 0.41$ & $8.59 \pm 0.49$ & $8.26 \pm 0.38$ & 2.118 & 0.107 \\
\hline Length (cm) & $18.45 \pm 1.42$ & $19.41 \pm 0.82$ & $18.91 \pm 1.57$ & $18.45 \pm 1.19$ & 2.043 & 0.117 \\
\hline Glu (mmol/l) & $73.48 \pm 4.27$ & $70.78 \pm 4.53$ & $69.24 \pm 5.76$ & $71.13 \pm 5.34$ & 1.957 & 0.130 \\
\hline Body mass before modeling (g) & $221.54 \pm 12.35$ & $227.12 \pm 14.24$ & $218.36 \pm 9.87$ & $216.63 \pm 11.58$ & 2.319 & 0.085 \\
\hline Body mass after modeling (g) & $212.63 \pm 7.57$ & $208.53 \pm 7.41$ & $206.47 \pm 7.82$ & $209.47 \pm 8.63$ & 1.697 & 0.177 \\
\hline Indoor temperature $\left({ }^{\circ} \mathrm{C}\right)$ & $24.05 \pm 1.24$ & $23.78 \pm 1.08$ & $24.25 \pm 0.93$ & $24.16 \pm 0.57$ & 0.682 & 0.566 \\
\hline Indoor humidity (\%) & $51.52 \pm 2.63$ & $50.74 \pm 1.93$ & $50.71 \pm 1.35$ & $49.93 \pm 1.07$ & 1.982 & 0.126 \\
\hline
\end{tabular}

Table III. Expression of EGF mRNA at different time-points in rats (mean $\pm \mathrm{SD}$ ).

\begin{tabular}{lccccr}
\hline Groups & 1 day $(\mathrm{n}=16)$ & 3 days $(\mathrm{n}=16)$ & 5 days $(\mathrm{n}=16)$ & 7 days $(\mathrm{n}=16)$ & F-value \\
\hline Study & $3.56 \pm 0.43$ & $8.43 \pm 0.76^{\mathrm{a}}$ & $16.63 \pm 1.25^{\mathrm{b}}$ & $7.93 \pm 0.97^{\mathrm{c}}$ & 582.700 \\
Control & $3.37 \pm 0.38$ & $8.63 \pm 0.83^{\mathrm{a}}$ & $11.67 \pm 1.77^{\mathrm{b}}$ & $9.46 \pm 1.56^{\mathrm{c}}$ & 123.700 \\
t-value & 0.489 & 0.515 & 12.760 & 3.937 & $<0.001$ \\
P-value & 0.626 & 0.608 & $<0.001$ & $<0.001$ & \\
\hline
\end{tabular}

${ }^{\mathrm{a}} \mathrm{P}<0.05$, compared to $1 \mathrm{st}$ day; ${ }^{\mathrm{b}} \mathrm{P}<0.05$, compared to $3 \mathrm{rd}$ day; ${ }^{\mathrm{C}} \mathrm{P}<0.05$, compared to 5 th day. EGF, epidermal growth factor.

Table IV. Expression of EGF protein at different time-points in rats (ng/ml) (mean $\pm \mathrm{SD})$.

\begin{tabular}{lccccr}
\hline Groups & 1 day $(\mathrm{n}=16)$ & 3 days $(\mathrm{n}=16)$ & 5 days $(\mathrm{n}=16)$ & 7 days $(\mathrm{n}=16)$ & F-value \\
\hline Study & $3.95 \pm 0.71$ & $5.46 \pm 0.94^{\mathrm{a}}$ & $12.26 \pm 1.07^{\mathrm{b}}$ & $6.85 \pm 1.26^{\mathrm{c}}$ & 203.500 \\
Control & $3.85 \pm 0.69$ & $5.71 \pm 1.03^{\mathrm{a}}$ & $10.57 \pm 1.53^{\mathrm{b}}$ & $8.69 \pm 1.46^{\mathrm{c}}$ & 95.920 \\
t-value & 0.251 & 0.628 & 4.248 & 4.625 & $<0.001$ \\
P-value & 0.802 & 0.531 & $<0.001$ & $<0.001$ & \\
\hline
\end{tabular}

${ }^{\mathrm{a}} \mathrm{P}<0.05$, compared to $1 \mathrm{st}$ day; ${ }^{\mathrm{b}} \mathrm{P}<0.05$, compared to $3 \mathrm{rd}$ day; ${ }^{\mathrm{C}} \mathrm{P}<0.05$, compared to 5 th day. EGF, epidermal growth factor.

Statistical analysis. Statistical analysis was performed using SPSS 19.0 (IBM Corp., Armonk, NY, USA). Measurement data were expressed as mean \pm standard deviation (mean $\pm \mathrm{SD}$ ). Chi-square test was used for the comparisons of inter-group count data. One-way ANOVA was used for the comparison of means among multiple groups. LSD-t-test was used for multiple comparisons between groups with LSD test as post hoc test. $\mathrm{P}<0.05$ indicates the difference is statistically significant.

\section{Results}

General condition of rats. One day after injury, wounds in the two groups began to heal. Wounds in the study group were smaller than those in the control group, and there were a small amount of granulation tissue on the wound surface. Three days after injury, wounds of the study group were significantly smaller than those of the control group, and the irregular granulation tissue was observed at the edge of the wound. Five days after injury, wounds of the two groups began to heal, and blood stasis was formed. The granulation tissue had shrunk, and the wound surface was closed. Seven days after injury, wound healing of the study group was better than that of the control group. Scar of the wound in the study group was better than that in the control group, and the wound surface was flatter compared with the control group. There were no differences in sex, age, length, blood glucose (Glu), body mass before and after modeling, indoor temperature and indoor humidity among group A, B, C and D (Table II).

Expressions of EGF $m R N A$ and protein at different timepoints in rats. Expressions of EGF mRNA and protein in the skin tissue of the study group were not significantly different from that of the control group at 1 and 3 days $(\mathrm{P}>0.05)$. At 3 days, expression levels of EGF mRNA and protein in skin tissue of the two groups were significantly higher than those 

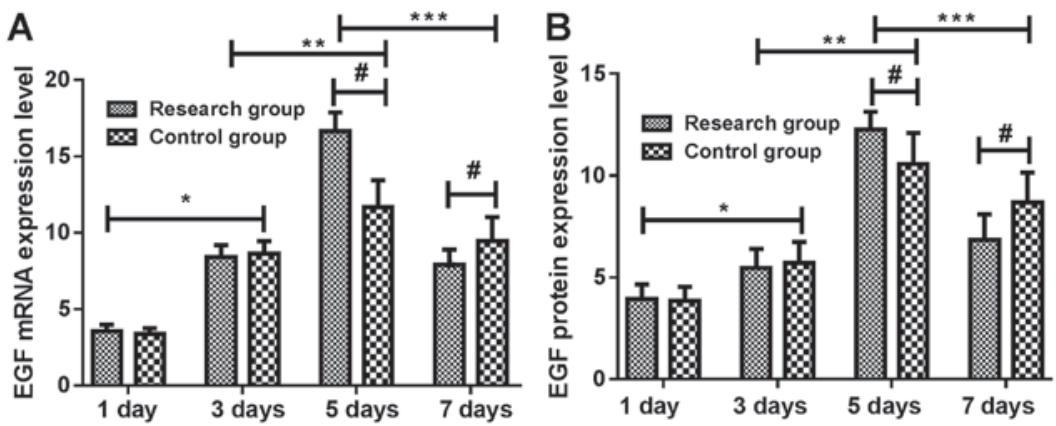

Figure 1. Changes in the expression levels of EGF mRNA and protein at different time-points in rats. The results of RT-qPCR and ELISA showed that the expression of EGF (A) mRNA and (B) protein in the skin of the study group were not significantly different from those of the control group at 1 and 3 days $(\mathrm{P}>0.05)$. At 3 days, expression levels of EGF mRNA and protein in skin tissue of study group and control group were significantly higher than those at 1 day $(\mathrm{P}<0.05)$. At 5 days, expression levels of EGF mRNA and protein in skin tissue of the two groups were significantly higher than those at 3 days $(\mathrm{P}<0.05)$, and the expression levels of EGF mRNA and protein in skin tissue of the study group were significantly higher than those of the control group ( $\mathrm{P}<0.05)$. At 7 days, expression levels of EGF mRNA and protein in skin tissue of the two groups were significantly lower than those at 5 days $(\mathrm{P}<0.05)$ and the expression levels of EGF mRNA and protein in skin tissue of the study group were significantly lower than those of the control group $(\mathrm{P}<0.05)$. " $\mathrm{P}<0.05,1$ vs. 3 days; ${ }^{* *} \mathrm{P}<0.05$, 3 vs. 5 days; ${ }^{* * * *} \mathrm{P}<0.05,5$ vs. 7 days; ${ }^{*} \mathrm{P}<0.05$, study vs. control group. EGF, epidermal growth factor; RT-qPCR, reverse transcription-quantitative PCR; ELISA, enzyme-linked immunosorbent assay.
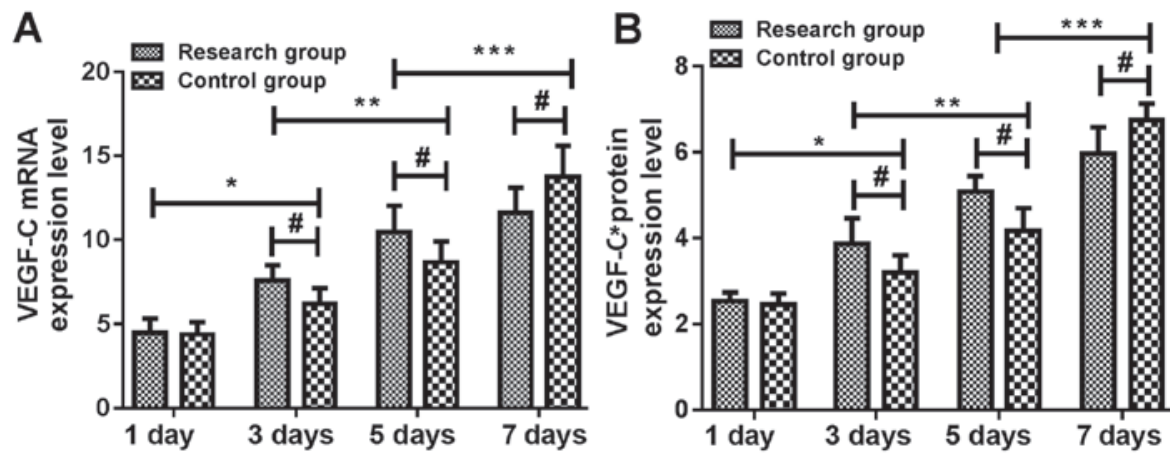

Figure 2. Changes in the expression levels of VEGF-C mRNA and protein at different time-points in rats. Results of RT-qPCR and ELISA showed that the expression of VEGF-C (A) mRNA and (B) protein in the skin of the study group were not significantly different from that of the control group at 1 day $(\mathrm{P}>0.05)$. At 3 and 5 days, expression levels of VEGF-C mRNA and protein in the skin tissue of the study group were significantly higher than those of the control group. At 3 days, expression levels of VEGF-C mRNA and protein in skin tissue of the two groups were significantly higher than those at 1 day $(\mathrm{P}<0.05)$. At 5 days, expression levels of VEGF-C mRNA and protein in skin tissue of the two groups were significantly higher than those at 3 days $(\mathrm{P}<0.05)$. At 7 days, expression levels of VEGF-C mRNA and protein in skin tissue of the two groups were significantly higher than those at 5 days and the expression levels of VEGF-C mRNA and protein in skin tissue of the study group were significantly lower than those of the control group $(\mathrm{P}<0.05)$. "P<0.05, 1 vs. 3 days; ${ }^{* * *} \mathrm{P}<0.05,3$ vs. 5 days; ${ }^{* * *} \mathrm{P}<0.05,5$ vs. 7 days; ${ }^{*} \mathrm{P}<0.05$, study vs. control group.

at 1 day $(\mathrm{P}<0.05)$. At 5 days, expression levels of EGF mRNA and protein in skin tissue of the two groups were significantly higher than those at 3 days $(\mathrm{P}<0.05)$, and the expression levels of EGF mRNA and protein in skin tissue of the study group were significantly higher than those of the control group $(\mathrm{P}<0.05)$. At 7 days, expression levels of EGF mRNA and protein in skin tissue of the two groups were significantly lower than those at 5 days $(\mathrm{P}<0.05)$ and the expression levels of EGF mRNA and protein in skin tissue of the study group were significantly lower than those of the control group $(\mathrm{P}<0.05)$ (Tables III and IV and Fig. 1).

Expression of VEGF-C $m R N A$ and protein at different timepoints in rats. Expression levels of VEGF-C mRNA and protein in skin tissue of the study group were not significantly ,different from those of the control group at 1 day $(\mathrm{P}>0.05)$. At 3 and 5 days, expression levels of VEGF-C mRNA and protein in the skin tissue of the study group were significantly higher than those of the control group. At 3 days, expression levels of VEGF-C mRNA and protein in skin tissue of the two groups were significantly higher than those at 1 day $(\mathrm{P}<0.05)$. At 5 days, expression levels of VEGF-C mRNA and protein in skin tissue of the two groups were significantly higher than those at 3 days $(\mathrm{P}<0.05)$. At 7 days, expression levels of VEGF-C mRNA and protein in skin tissue of the two groups were significantly higher than those at 5 days $(\mathrm{P}<0.05)$ and the expression levels of VEGF-C mRNA and protein in skin tissue of the study group were significantly lower than those of the control group $(\mathrm{P}<0.05)$ (Tables V and VI and Fig. 2).

\section{Discussion}

Scar formed after wound healing is a clinical problem. The requirements for the prognosis of wounds are getting higher, and scar-free wound repair is expected. Therefore, the scar healing after wound healing has become a research hotspot for scholars $(12,13)$. Healing process of oral mucosa is rapid, with few scars. Therefore, oral mucosal healing is of importance 
Table V. Expression levels of VEGF-C mRNA at different time-points in rats (mean \pm SD).

\begin{tabular}{|c|c|c|c|c|c|c|}
\hline Groups & 1 day $(n=16)$ & 3 days $(n=16)$ & 5 days $(n=16)$ & 7 days $(n=16)$ & F-value & P-value \\
\hline Study & $4.47 \pm 0.86$ & $7.58 \pm 0.93^{\mathrm{a}}$ & $10.47 \pm 1.57^{\mathrm{b}}$ & $11.63 \pm 1.47^{\mathrm{c}}$ & 105.300 & $<0.001$ \\
\hline Control & $4.38 \pm 0.72$ & $6.19 \pm 0.95^{\mathrm{a}}$ & $8.67 \pm 1.24^{b}$ & $13.76 \pm 1.85^{\mathrm{c}}$ & 166.400 & $<0.001$ \\
\hline t-value & 0.203 & 3.131 & 4.055 & 4.798 & & \\
\hline P-value & 0.840 & 0.002 & $<0.001$ & $<0.001$ & & \\
\hline
\end{tabular}

${ }^{\mathrm{a}} \mathrm{P}<0.05$, compared to 1 st day; ${ }^{\mathrm{b}} \mathrm{P}<0.05$, compared to $3 \mathrm{rd}$ day; ${ }^{\mathrm{C}} \mathrm{P}<0.05$, compared to 5 th day. VEGF-C, vascular endothelial growth factor $\mathrm{C}$.

Table VI. Expression levels of VEGF-C protein $(\mathrm{ng} / \mathrm{ml})$ at different time-points in rats (mean $\pm \mathrm{SD})$.

\begin{tabular}{lccccr}
\hline Groups & 1 day $(\mathrm{n}=16)$ & 3 days $(\mathrm{n}=16)$ & 5 days $(\mathrm{n}=16)$ & 7 days $(\mathrm{n}=16)$ & F-value \\
\hline Study & $2.53 \pm 0.21$ & $3.87 \pm 0.59^{\mathrm{a}}$ & $5.08 \pm 0.47^{\mathrm{b}}$ & $5.97 \pm 0.61^{\mathrm{c}}$ & 145.100 \\
Control & $2.46 \pm 0.26$ & $3.19 \pm 0.41^{\mathrm{a}}$ & $4.17 \pm 0.53^{\mathrm{b}}$ & $6.75 \pm 0.64^{\mathrm{c}}$ & 242.700 \\
t-value & 0.405 & 3.935 & 5.266 & 4.513 & $<0.001$ \\
P-value & 0.686 & $<0.001$ & $<0.001$ & $<0.001$ & \\
\hline
\end{tabular}

${ }^{\text {a }} \mathrm{P}<0.05$, compared to $1 \mathrm{st}$ day; ${ }^{\text {b }} \mathrm{P}<0.05$, compared to $3 \mathrm{rd}$ day; ${ }^{\mathrm{c}} \mathrm{P}<0.05$, compared to 5 th day. VEGF-C, vascular endothelial growth factor $\mathrm{C}$.

in the deeper understanding of skin wound repair $(14,15)$. This study transplanted the rat tongue mucosa to the right abdomen skin, made a full-thickness skin wound and observed biological indicators that may become factors of scar formation, providing a theoretical basis for scar wound healing.

When the body is damaged, cells and tissues at the wound site will secrete a large number of wound healing growth factors. Growth factors are cytokines that stimulate cell growth activity and play an important role in the body wound repair process (16). Cytokines can attract fibroblasts and inflammatory cells into the wound, which promotes vascularization and cell proliferation of the wound (17). EGF is a novel type of polypeptide factor found in the purification of mouse submandibular gland nerve growth factor. It is a biologically active substance that stimulates cell proliferation and is widely distributed in tissues and body fluids $(18,19)$. EGF may be one of the most characterized growth factors in the process of skin wound healing. In acute trauma, EGF is mainly secreted by platelets, macrophages and fibroblasts, and is upregulated in a short time after injury (20,21). Release of EGF stimulates migration and proliferation of epithelial cells, thereby promoting re-epithelialization (22). Kim et al (23) found that EGF can reduce the expression of TGF- $\beta$, reduce skin scars, and mediate collagen formation by inhibiting inflammatory response. During the process of lymphangiogenesis, it can be stimulated by various cytokines, including VEGF-C. VEGF-C is the first identified ligand of growth factor receptor 3 (Flt4) and is a member of the polypeptide growth factor family $(24,25)$. It has been shown that overexpressed VEGF-C cDNA in the skin of transgenic mice can induce lymphatic endothelial cell proliferation and lymphangiogenesis, recombinant VEGF-C and can specifically stimulate lymphangiogenesis in the chorioallantoic membrane (26). Results of this study showed that expression levels of EGF and VEGF-C mRNA and protein in skin tissue of the two groups were significantly higher at 3 days than at 1 day; expression levels of EGF and VEGF-C mRNA and protein in skin tissue of the two groups were significantly higher at 5 days than at 3 days; expression levels of EGF mRNA and protein in skin tissue of the two groups were significantly lower at 7 days than at 5 days, while expression levels of VEGF-C mRNA and protein were significantly higher at 7 days than at 5 days. It is suggested that EGF and VEGF-C may be involved in scar formation. Irregular granulation tissue appeared on the 3rd day after injury, and blood stasis formed on the 5th day. Hyperplasia of rat skin repair tissue cells and wound healing began from this stage. In this study, expression levels of VEGF-C mRNA and protein in skin tissue of the study group were significantly higher than those of the control group at 3 days. Expression levels of EGF and VEGF-C mRNA and protein in skin tissue of the study group were significantly higher than those of the control group at 5 days. At 7 days, expression levels of EGF and VEGF-C mRNA and protein in skin tissue of the study group were significantly lower than those of the control group. It is suggested that oral mucosal transplantation has the characteristics of quick repair and good effect in skin wound repair. EGF and VEGF-C may play an important role in skin wound repair.

Previous studies have shown that exogenous growth factors can promote scar-free healing of wounds. However, the separation of growth factors remains to be studied, because the level of growth factor is low in the body. Determination of appropriate concentration of growth factor and the regulation of it to interfere with cell proliferation is of great significance for wound healing to reduce scar formation, which will be the focus of our future study.

In summary, EGF and VEGF-C may be involved in scar formation and play an important role in the process of skin wound repair.

\section{Acknowledgements}

Not applicable. 


\section{Funding}

No funding was received.

\section{Availability of data and materials}

The datasets used and/or analyzed during the present study are available from the corresponding author on reasonable request.

\section{Authors' contributions}

SQ wrote the manuscript, interpreted the data and drafted the manuscript. CY assisted with the construction of the animal model. MZ and HC performed PCR and ELISA. All the authors read and approved the final manuscript.

\section{Ethics approval and consent to participate}

The investigation was approved by the Ethics Committee of Jinan Maternity and Child Care Hospital (Jinan, China) and the experimental procedures were in compliance with the Guiding Principles for the Protection and Use of Experimental Animals (10). Patients who participated in this research had complete clinical data. Signed informed consents were obtained from the patients or the guardians.

\section{Patient consent for publication}

Not applicable.

\section{Competing interests}

The authors declare that they have no competing interests.

\section{References}

1. Yu J, Wang MY, Tai HC and Cheng NC: Cell sheet composed of adipose-derived stem cells demonstrates enhanced skin wound healing with reduced scar formation. Acta Biomater 77: 191-200, 2018.

2. Asatiani E, Huang WX, Wang A, Rodriguez Ortner E, Cavalli LR, Haddad BR and Gelmann EP: Deletion, methylation, and expression of the NKX3.1 suppressor gene in primary human prostate cancer. Cancer Res 65: 1164-1173, 2005.

3. Tracy LE, Minasian RA and Caterson EJ: Extracellular matrix and dermal fibroblast function in the healing wound. Adv Wound Care (New Rochelle) 5: 119-136, 2016.

4. Purba ER, Saita EI and Maruyama IN: Activation of the EGF receptor by ligand binding and oncogenic mutations: The 'Rotation Model'. Cells 6: 6, 2017.

5. Basso FG, Soares DG, Pansani TN, Cardoso LM, Scheffel DL, de Souza Costa CA and Hebling J: Proliferation, migration, and expression of oral-mucosal-healing-related genes by oral fibroblasts receiving low-level laser therapy after inflammatory cytokines challenge. Lasers Surg Med 48: 1006-1014, 2016.

6. Hominick D, Silva A, Khurana N, Liu Y, Dechow PC, Feng JQ, Pytowski B, Rutkowski JM, Alitalo K and Dellinger MT: VEGF-C promotes the development of lymphatics in bone and bone loss. eLife 7: e34323, 2018.

7. Chilov D, Kukk E, Taira S, Jeltsch M, Kaukonen J, Palotie A, Joukov V and Alitalo K: Genomic organization of human and mouse genes for vascular endothelial growth factor C. J Biol Chem 272: 25176-25183, 1997.

8. Kosten IJ, van de Ven R, Thon M, Gibbs S and de Gruijl TD: Comparative phenotypic and functional analysis of migratory dendritic cell subsets from human oral mucosa and skin. PLoS One 12: e0180333, 2017.
9. Song IB, Gu H, Han HJ, Lee NY, Cha JY, Son YK and Kwon J: Effects of 7-MEGA ${ }^{\mathrm{TM}} 500$ on oxidative stress, inflammation, and skin regeneration in $\mathrm{H}_{2} \mathrm{O}_{2}$-treated skin cells. Toxicol Res 34: 103-110, 2018.

10. Sikes RS; Animal Care and Use Committee of the American Society of Mammalogists: 2016 Guidelines of the American Society of Mammalogists for the use of wild mammals in research and education. J Mammal 97: 663-688, 2016.

11. Livak KJ and Schmittgen TD: Analysis of relative gene expression data using real-time quantitative PCR and the 2 [-Delta Delta C(T)] method. Methods 25: 402-408, 2001.

12. Ramos-Lewis W, LaFever KS and Page-McCaw A: A scar-like lesion is apparent in basement membrane after wound repair in vivo. Matrix Biol 74: 101-120, 2018.

13. Occleston NL, Metcalfe AD, Boanas A, Burgoyne NJ, Nield K, O'Kane S and Ferguson MW: Therapeutic improvement of scarring: mechanisms of scarless and scar-forming healing and approaches to the discovery of new treatments. Dermatol Res Pract 2010: 405262, 2010.

14. DiPietro LA: Angiogenesis and wound repair: When enough is enough. J Leukoc Biol 100: 979-984, 2016.

15. Iglesias-Bartolome R, Uchiyama A, Molinolo AA, Abusleme L, Brooks SR, Callejas-Valera JL, Edwards D, Doci C, Asselin-Labat ML, Onaitis MW, et al: Transcriptional signature primes human oral mucosa for rapid wound healing. Sci Transl Med 10: eaap8798, 2018.

16. Han J, Jin W, Ho NA, Hong J, Kim YJ, Shin Y, Lee H and Suh JW: Decursin and decursinol angelate improve wound healing by upregulating transcription of genes encoding extracellular matrix remodeling proteins, inflammatory cytokines, and growth factors in human keratinocytes. Biochem Biophys Res Commun 499: 979-984, 2018.

17. Velasquez LS, Sutherland LB, Liu Z, Grinnell F, Kamm KE, Schneider JW, Olson EN and Small EM: Activation of MRTF-Adependent gene expression with a small molecule promotes myofibroblast differentiation and wound healing. Proc Natl Acad Sci USA 110: 16850-16855, 2013.

18. Kris MG, Natale RB, Herbst RS, Lynch TJ Jr, Prager D, Belani CP, Schiller JH, Kelly K, Spiridonidis H, Sandler A, et al: Efficacy of gefitinib, an inhibitor of the epidermal grow th factor receptor tyrosine kinase, in symptomatic patients with non-small cell lung cancer: A randomized trial. JAMA 290: 2149-2158, 2003.

19. Stoddard MA, Herrmann J, Moy L and Moy R: Improvement of atrophic acne scars in skin of color using topical synthetic epidermal growth factor (EGF) serum: A pilot study. J Drugs Dermatol 16: 322-326, 2017.

20. Shiraha H, Glading A, Gupta K and Wells A: IP-10 inhibits epidermal growth factor-induced motility by decreasing epidermal growth factor receptor-mediated calpain activity. J Cell Biol 146: 243-254, 1999.

21. Schultz G, Rotatori DS and Clark W: EGF and TGF-alpha in wound healing and repair. J Cell Biochem 45: 346-352, 1991.

22. Haase I, Evans R, Pofahl R and Watt FM: Regulation of keratinocyte shape, migration and wound epithelialization by IGF-1- and EGF-dependent signalling pathways. J Cell Sci 116: 3227-3238, 2003.

23. Kim YS, Lew DH, Tark KC, Rah DK and Hong JP: Effect of recombinant human epidermal growth factor against cutaneous scar formation in murine full-thickness wound healing. J Korean Med Sci 25: 589-596, 2010.

24. Leak LV and Jones M: Lymphangiogenesis in vitro: Formation of lymphatic capillary-like channels from confluent monolayers of lymphatic endothelial cells. In Vitro Cell Dev Biol Anim 30: 512-518, 1994.

25. Oh SJ, Jeltsch MM, Birkenhäger R, McCarthy JE, Weich HA, Christ B, Alitalo K and Wilting J: VEGF and VEGF-C: Specific induction of angiogenesis and lymphangiogenesis in the differentiated avian chorioallantoic membrane. Dev Biol 188: 96-109, 1997.

26. Jeltsch M, Kaipainen A, Joukov V, Meng X, Lakso M, Rauvala H, Swartz M, Fukumura D, Jain RK and Alitalo K: Hyperplasia of lymphatic vessels in VEGF-C transgenic mice. Science 276: 1423-1425, 1997. International (CC BY-NC-ND 4.0) License. 